\title{
Manganese-Catalyzed Aerobic Heterocoupling of Aryl Grignard Reagents
}

\author{
Ghaleshahi, Hajar Golshahi; Antonacci, Giuseppe; Madsen, Robert
}

Published in:

European Journal of Organic Chemistry

Link to article, DOI:

10.1002/ejoc.201700007

Publication date:

2017

Document Version

Peer reviewed version

Link back to DTU Orbit

Citation (APA):

Ghaleshahi, H. G., Antonacci, G., \& Madsen, R. (2017). Manganese-Catalyzed Aerobic Heterocoupling of Aryl Grignard Reagents. European Journal of Organic Chemistry, 2017(10), 1331-1336.

https://doi.org/10.1002/ejoc.201700007

\section{General rights}

Copyright and moral rights for the publications made accessible in the public portal are retained by the authors and/or other copyright owners and it is a condition of accessing publications that users recognise and abide by the legal requirements associated with these rights.

- Users may download and print one copy of any publication from the public portal for the purpose of private study or research.

- You may not further distribute the material or use it for any profit-making activity or commercial gain

- You may freely distribute the URL identifying the publication in the public portal

If you believe that this document breaches copyright please contact us providing details, and we will remove access to the work immediately and investigate your claim. 


\title{
Manganese-Catalyzed Aerobic Heterocoupling of Aryl Grignard Reagents
}

\author{
Hajar Golshahi Ghaleshahi, ${ }^{[a]}$ Giuseppe Antonacci, ${ }^{[a]}$ and Robert Madsen ${ }^{*[a]}$
}

\begin{abstract}
An improved protocol has been developed for the $\mathrm{MnCl}_{2-}$ catalyzed cross coupling of two arylmagnesium bromides under an atmosphere of dioxygen. The reaction is achieved with a 2:1 ratio between the Grignard reagents and $20 \%$ of $\mathrm{MnCl}_{2}$. Very good yields of the heterocoupling product can be obtained when the limiting Grignard regent undergoes very little homocoupling under the reaction conditions. Arylmagnesium bromides with $p$-methoxy, $p$ dimethylamino, $p$-fluoro and $p$-chloro substituents were shown to give high yields in the cross coupling with a variety of substituted aryl Grignard reagents. Heterocyclic Grignard reagents, on the other hand, were less effective substrates for the transformation due to a rapid homocoupling with these reagents.
\end{abstract}

\section{Introduction}

The biaryl structural motif is an important subunit in many pharmaceuticals, agrochemicals, conducting materials and natural products. ${ }^{[1]}$ The synthesis of biaryl compounds can be performed by a metal-catalyzed cross coupling reaction between aryl halides and various arylmetal (or -boron) species. ${ }^{[1 \mathrm{~b}, \mathrm{c}]}$ An important alternative is the oxidative coupling of two arylmetal compounds $^{[2]}$ where the reaction with Grignard reagents is particularly attractive due to the ease of their formation. The oxidative homocoupling of organomagnesium halides has been described with a range of different catalysts and stoichiometric oxidants. This includes iron, copper, cobalt, manganese, nickel and ruthenium catalysts with dioxygen, a diaziridinone and a 1,2-dihaloethane as the terminal oxidizing agents. ${ }^{[3]}$ In addition, several organocatalysts have been employed as electron acceptors in the presence of dioxygen as the equimolar oxidant. ${ }^{[4]} A$ number of stoichiometric reagents have also been presented for the homocoupling of arylmagnesium halides where a catalyst is not necessary. ${ }^{[5]}$

On the contrary, the corresponding cross coupling of two different Grignard reagents has only received little attention. In 2009, the aerobic heterocoupling was investigated with $\mathrm{CoCl}_{2}$ as the catalyst, but the reaction gave mostly statistical mixtures of products and only with a 2:1 ratio between the Grignard reagents was it possible to obtain around $60 \%$ yield of the desired coupling product. ${ }^{[6]}$ In the same year, the $\mathrm{MnCl}_{2} \cdot 2 \mathrm{LiCl}-$ catalyzed cross coupling of two Grignard reagents was studied

[a] Department of Chemistry, Technical University of Denmark, 2800 Kgs. Lyngby, Denmark

E-mail: rm@kemi.dtu.dk

http://www.kemi.dtu.dk

Supporting information for this article is given via a link at the end of the document. and in this case $59-81 \%$ yield was obtained with 2.5 equiv. of one Grignard reagent. ${ }^{[7]}$ It was noted that electron rich Grignard reagents reacted faster than electron poor species and the electronic factor may be used to influence the selectivity for the heterocoupling product. The reactions were conducted with $70 \%{ }^{[8]}$ of the manganese catalyst in THF solution at $0{ }^{\circ} \mathrm{C}$ under an atmosphere of dioxygen and a total of 8 biaryl compounds were prepared in this way. ${ }^{[7]}$ In all cases, an electron rich Grignard reagent was employed as one of the coupling partners. The mechanism was recently investigated by DFT calculations and a manganese(II) - (IV) cycle was proposed through the sequence $\mathrm{R}_{2} \mathrm{Mn}(\mathrm{II}) \rightarrow \mathrm{R}_{2} \mathrm{Mn}(\mathrm{IV})\left(\mathrm{O}_{2}\right) \rightarrow \mathrm{R}-\mathrm{R}+\mathrm{Mn}(\mathrm{II})\left(\mathrm{O}_{2}\right) \rightarrow$ $\mathrm{R}_{2} \mathrm{Mn}$ (II). ${ }^{[9]}$ The formation of organomanganese species from organomagnesium halides and $\mathrm{MnCl}_{2}$ has been investigated earlier and complete conversion is observed upon mixing the reagents in THF solution. ${ }^{10]}$

We have previously studied the reactivity of Grignard reagents ${ }^{[11]}$ and used $\mathrm{MnCl}_{2}$ as a catalyst for a radical-mediated C-C coupling reaction. ${ }^{[12]}$ We speculated that the manganesecatalyzed aerobic coupling of Grignard reagents could be improved and applied to a wider variety of substrates. It should be possible to use a lower amount of the manganese catalyst and to obtain a higher yield of the heterocoupling product. Herein, we describe our optimized procedure for the $\mathrm{MnCl}_{2}$ catalyzed aerobic cross coupling of aryl Grignard reagents.

\section{Results and Discussion}

Phenyl- and p-methoxyphenylmagnesium bromide were selected as the two Grignard reagents for the initial experiments. THF was employed as the solvent since $\mathrm{MnCl}_{2}$ is soluble in this solution in the presence of $\mathrm{LiCl}$. On the contrary, $\mathrm{MnCl}_{2}$ is not soluble in $\mathrm{Et}_{2} \mathrm{O}$ resulting in a very slow transmetallation with organomagnesium halides in $\mathrm{Et}_{2} \mathrm{O} .{ }^{[10]}$ The conditions for the heterocoupling involve mixing of the components at $-5{ }^{\circ} \mathrm{C}$, stirring for $5 \mathrm{~min}$ and then allowing a flow of dioxygen to pass through the solution. ${ }^{[7]}$ Under these conditions we obtained a $67 \%$ GC yield of 4-methoxybiphenyl (Table 1, Entry 1) while $80 \%$ was reported in the earlier study. ${ }^{[7]}$ The yield did not change by using the corresponding chlorides of the Grignard reagents while a slightly lower yield was obtained with dry air instead og dioxygen. With $20 \%$ of the manganese catalyst the yield of 4-methoxybiphenyl dropped to a mere $40 \%$ (Entry 2). However, stirring the mixture for more than $5 \mathrm{~min}$ and at a lower temperature before the addition of dioxygen turned out to have a significant impact on the outcome (Entries 3-5). No reaction occurred before the addition of dioxygen, but the color of the mixture changed from yellow to green by stirring for $10-20 \mathrm{~min}$ after mixing the reactants. With the longer mixing time and a lower temperature the heterocoupling yield could now be 
improved to $96 \%$. This also made it possible to use a lower amount of the catalyst where essentially the same results were obtained with $50 \%, 30 \%$ and $20 \%$ of $\mathrm{MnCl}_{2}$ while $10 \%$ of $\mathrm{MnCl}_{2}$ gave a moderate yield due to incomplete conversion of the starting materials (Entries 6-10). In addition, the ratio between the two Grignard reagents could be lowered to 2:1 which gave the same result as with the 2.5:1 ratio. The reaction mixture turned black during the addition of dioxygen and a side reaction presumably involves oxidation of manganese(II) to higher valent and inactive species which would explain the need for $20 \%$ of $\mathrm{MnCl}_{2}$. A control experiment revealed that no reaction occurred when $\mathrm{MnCl}_{2}$ was replaced with $\mathrm{MnO}_{2}$. As a result, our modified procedure for the heterocoupling employs $20 \%$ of $\mathrm{MnCl}_{2}$ and stirring the reactants at $-10{ }^{\circ} \mathrm{C}$ for at least $20 \mathrm{~min}$ before the addition of dioxygen.

Table 1. Optimization of the $\mathrm{MnCl}_{2}$-catalyzed aerobic cross coupling

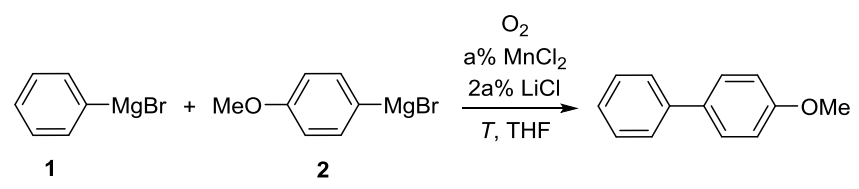

\begin{tabular}{llllll}
\hline Entry & $\mathbf{1}: \mathbf{2}$ & $\begin{array}{l}\text { Mixing time of } \mathbf{1} \\
\text { and } 2[\mathrm{~min}]\end{array}$ & $\mathrm{a}$ & $T\left[{ }^{\circ} \mathrm{C}\right]$ & Yield [\% $]^{[\mathrm{a}]}$ \\
\hline 1 & $2.5: 1$ & 5 & 70 & -5 & $67^{[\mathrm{b}]}$ \\
2 & $2.5: 1$ & 5 & 20 & -5 & 40 \\
3 & $2.5: 1$ & 10 & 70 & -5 & 86 \\
4 & $2.5: 1$ & 20 & 70 & -5 & 88 \\
5 & $2.5: 1$ & 20 & 70 & -15 & 96 \\
6 & $2: 1$ & 20 & 70 & -10 & 96 \\
7 & $2: 1$ & 20 & 50 & -10 & 96 \\
8 & $2: 1$ & 20 & 30 & -10 & 95 \\
9 & $2: 1$ & 20 & 20 & -10 & 95 \\
10 & $2: 1$ & 20 & 10 & -10 & 57 \\
\hline
\end{tabular}

[a] GC yield. [b] $8 \%$ of 4,4'-dimethoxybiphenyl was also obtained.

Under these conditions a 95\% yield of 4-methoxybiphenyl was obtained with a 2:1 ratio of the two Grignard reagents (Table 1, Entry 9). Clearly, the two starting materials do not react to give a pure statistical mixture of the homo- and heterocoupling products which would only result in $67 \%$ of 4-methoxybiphenyl. The explanation came by monitoring the coupling during the first 6 min by withdrawing samples and quenching with iodine. This showed that $p$-methoxyphenylmagnesium bromide undergoes very little homocoupling while the homocoupling of phenylmagnesium bromide and the desired heterocoupling occur to approximately the same degree (Figure 1). Consequently, the heterocoupling may afford a very high yield when the limiting Grignard reagent, on which the yield is based, does not homocouple under the reaction conditions. This was noticed in Table 1, Entries $3-9$ where only $2-3 \%$ of 4,4 dimethoxybiphenyl was formed. If the reactants are not allowed to stir for 20 min before the addition of dioxygen, the amount of 4,4'-dimethoxybiphenyl increases, which was observed in Table 1 , Entry 1 and also reported in the earlier study. ${ }^{[7]}$

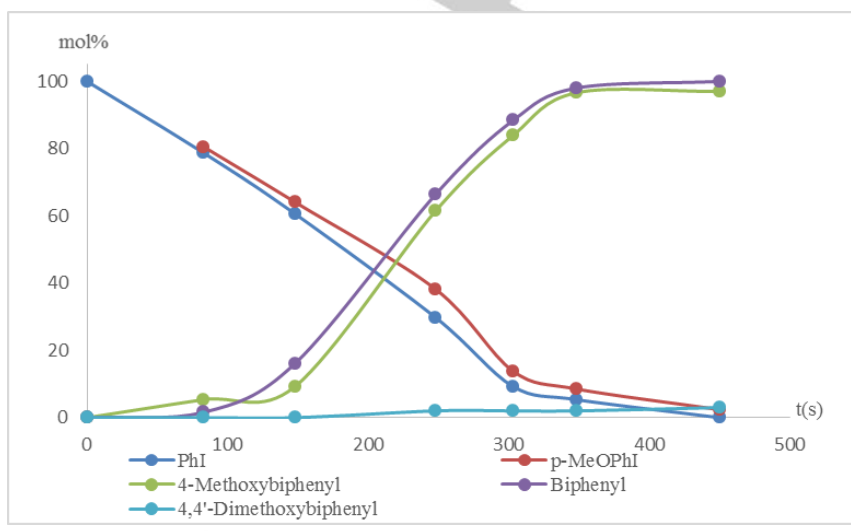

Figure 1. Progress of coupling reaction.

With the modified protocol in hand the scope of the aerobic cross coupling could now be explored in further detail (Table 2). 4-Methoxybiphenyl was isolated in $91 \%$ yield from the coupling between phenyl- and p-methoxyphenylmagnesium bromide under the optimized conditions (Entry 1). A similar yield was obtained when $p$-methoxyphenylmagnesium bromide was reacted with $p$-dimethylaminophenyl- and $p$ cyanophenylmagnesium bromide (Entries 2 and 3). The coupling with 2-thienyl- and 3-pyridylmagnesium bromide, on the other hand, gave lower yields (Entries $4-5$ ), which is presumably due to the very fast homocoupling of these two heterocyclic Grignard reagents.

Table 2. Aerobic cross coupling of different Grignard reagents.

$$
\begin{aligned}
& \mathrm{O}_{2} \\
& 20 \% \mathrm{MnCl}_{2}
\end{aligned}
$$

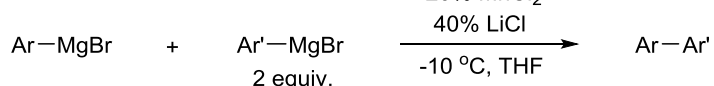

Entry $\mathrm{Ar}-\mathrm{MgBr} \quad \mathrm{Ar}-\mathrm{MgBr}$


3<smiles>[B][N+](Br)(c1ccc(C#N)cc1)c1ccc(OC)cc1</smiles>

4<smiles>COc1ccc(-c2cccs2)cc1</smiles><smiles>COc1ccc([R18](Br)Br)cc1</smiles><smiles>Cc1ccc([Mg]Br)cc1</smiles>

$\mathrm{NMe}_{2}$<smiles>Brc1ccccc1</smiles><smiles>Brc1ccc(Br)cc1</smiles>

8<smiles>CN(C)c1ccc(C(Br)(Br)Br)cc1</smiles><smiles></smiles>

10<smiles>CCBr</smiles>

11

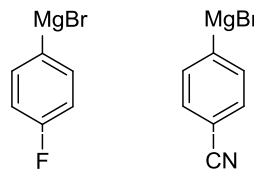<smiles>Fc1ccc(Br)cc1</smiles>

13<smiles>COc1ccc(-c2ccc(C#N)cc2)cc1</smiles>

89<smiles>COc1ccc(-c2cccnc2)cc1</smiles><smiles>O=[N+]([O-])c1ccc(-c2ccccc2)cc1</smiles>

99<smiles>Brc1ccc([N+](Br)(Br)Br)cc1</smiles><smiles>CN(C)c1ccc(-c2ccc(F)cc2)cc1</smiles><smiles>CN(C)c1ccc(-c2ccc(F)cc2)cc1</smiles><smiles>Fc1ccc(-c2ccccc2)cc1</smiles><smiles>Cc1ccc([Mg]Br)cc1</smiles>

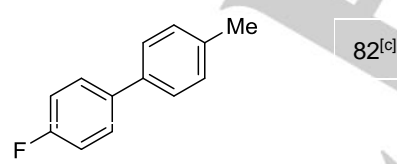<smiles>N#Cc1ccc(-c2ccc(F)cc2)cc1</smiles>
CN<smiles>Clc1ccc(Br)cc1</smiles><smiles>Fc1ccc(-c2ccc(Cl)cc2)cc1</smiles>

$84^{[c]}$
14<smiles>Clc1ccc(-c2ccc(Cl)cc2)cc1</smiles>

15<smiles>COc1ccc(-c2ccc(Cl)cc2-c2ccc(OC)cc2)cc1</smiles>

87

51

16<smiles>Cc1ccc(Br)cc1</smiles>

17<smiles>Cc1ccc(F)cc1</smiles>

50

$70^{[c]}$

70

64<smiles>Clc1cccc([18Br])c1</smiles><smiles>Br[Mg]c1ccccc1</smiles><smiles>Clc1cccc(-c2ccccc2)c1</smiles>

22<smiles>Br[Mg]c1ccccc1</smiles><smiles></smiles>

81 0<smiles>CCC</smiles><smiles>CCC</smiles>

76

[a] Isolated yield. [b] GC yield. [c] Yield based on NMR since isolated product not completely pure.

p-Dimethylaminophenylmagnesium bromide is also a Grignard reagents that undergoes very little homocoupling under the reaction conditions. As a result, very high yields could be obtained in the heterocoupling with phenyl- and $p$ fluorophenylmagnesium bromide (Entries 6 and 7). During the latter experiment it was discovered that the para-fluoro reagent reacted faster in the heterocoupling than in the homocoupling. Consequently, it should be possible to use Grignard reagents 
with electron-withdrawing groups as the limiting agent and still obtain a good yield in the cross coupling. Reversing the two coupling partners in Entry 7 gave only a slightly lower yield (Entry 8). Coupling of $p$-fluorophenylmagnesium bromide with phenyl-, $p$-tolyl-, $p$-cyanophenyl- and $p$-chlorophenylmagnesium bromide gave the corresponding biphenyl products in similar yields (Entries $9-12$ ). Reversing the Grignard reagents in the last experiment led to only a small decrease in the yield (Entry 13) showing that $p$-chlorophenylmagnesium bromide also reacts slower in the homocoupling than in the heterocoupling. This was confirmed by reacting $p$-chlorophenylmagnesium bromide with phenylmagnesium bromide to give 4-chlorobiphenyl in $81 \%$ yield (Entry 14). The same reaction with $p$-methoxyphenylmagnesium bromide increased the yield to $87 \%$ due to the slow homocoupling of the latter (Entry 15). Coupling of $p$ fluorophenylmagnesium bromide with several heterocyclic Grignard reagents led to moderate yields (Entries $16-18$ ), which is presumably caused by the rapid homocoupling of these heterocyclic reagents as noted above.

Grignard reagents with ortho and meta substituents could also be used in the cross coupling. The reaction between 0 methoxyphenylmagnesium bromide and phenylmagnesium bromide afforded the product in $70 \%$ yield (Entry 19) while the transformation with several meta-substituted reagents gave moderate to good yields (Entries $20-22$ ). The lower yield with the ortho-substituted substrate in Entry 19 illustrates the influence of steric effects when compared with the para reagent in Entry 1.

\section{Conclusions}

In summary, we have developed an improved protocol for the $\mathrm{MnCl}_{2}$-catalyzed aerobic cross coupling of arylmagnesium halides. It is important to allow the two Grignard reagents to react with $\mathrm{MnCl}_{2}$ before the addition of dioxygen since the subsequent oxidative coupling is a very fast reaction. Under these conditions high yields could be obtained in a number of cases with a 2:1 ratio between the Grignard reagents and 20\% of $\mathrm{MnCl}_{2}$. The successful cross couplings were achieved when the limiting arylmagnesium halide show only little inclination to undergo a competing self-coupling. Very little homocoupling was observed with $p$-methoxy- and $p$ dimethylaminophenylmagnesium bromide while relatively little homocoupling occurred with $p$-fluoro- and $p$ chlorophenylmagnesium bromide. The successful coupling of Grignard reagents with electron-withdrawing substituents constitutes a new development for this transformation. Heterocyclic Grignard reagents, on the other hand, were not good coupling partners since the self-coupling with these reagents is a fast reaction.

\section{Experimental Section}

General: Gas chromatography was performed on a Shimadzu GCMSQP2010S instrument fitted with an Equity $5,30 \mathrm{~m} \times 0.25 \mathrm{~mm} \times 0.25 \mu \mathrm{m}$ column. Flash column chromatography separations were performed on silica gel $60(40-63 \mu \mathrm{m})$. NMR spectra were recorded on a Bruker Ascend 400 spectrometer. Chemical shifts were measured relative to the signals of residual $\mathrm{CHCl}_{3}\left(\delta_{\mathrm{H}}=7.26 \mathrm{ppm}\right)$ and $\mathrm{CDCl}_{3}(\delta \mathrm{c}=77.16 \mathrm{ppm})$. HRMS measurements were made using ESI with TOF detection.

Grignard reagents: The heterocyclic Grignard reagents and $p$ cyanophenylmagnesium bromide were prepared from the corresponding bromides and magnesium in THF while the remaining reagents were purchased from commercial suppliers. All Grignard reagents were titrated with a $0.06 \mathrm{M}$ solution of $\mathrm{I}_{2}$ in $\mathrm{Et}_{2} \mathrm{O}$ to determine the concentration: phenylmagnesium bromide (1.5 $\mathrm{M}$ in 2-methyltetrahydrofuran), $p$ methoxyphenylmagnesium bromide $(0.6 \mathrm{M}$ in THF), $p$ dimethylaminophenylmagnesium bromide $(0.3 \mathrm{M}$ in THF), $p$ cyanophenylmagnesium bromide $(0.5 \mathrm{M}$ in THF), 2-thienylmagnesium bromide (1.2 M in THF), 3-pyridylmagnesium bromide (0.5 M in THF), $p$ fluorophenylmagnesium bromide $(0.5 \mathrm{M}$ in THF), $p$-tolylmagnesium bromide $\left(0.3 \mathrm{M}\right.$ in $\left.\mathrm{Et}_{2} \mathrm{O}\right)$, p-chlorophenylmagnesium bromide $(0.5 \mathrm{M}$ in $\left.\mathrm{Et}_{2} \mathrm{O}\right)$, 2-furylmagnesium bromide $(0.2 \mathrm{M}$ in THF), omethoxyphenylmagnesium bromide $(0.6 \mathrm{M}$ in THF), $m$ fluorophenylmagnesium bromide $(0.6 \mathrm{M}$ in THF), $m$ chlorophenylmagnesium bromide $(0.3 \mathrm{M}$ in THF), and $m$ methoxyphenylmagnesium bromide $(0.6 \mathrm{M}$ in THF),

General Procedure for Aerobic Heterocoupling of Two Grignard Reagents: A dry three-neck round-bottom flask was equipped with a stir bar, a thermometer and a nitrogen inlet. The flask was flushed with nitrogen and charged with $\mathrm{MnCl}_{2}(51 \mathrm{mg}, 0.405 \mathrm{mmol}), \mathrm{LiCl}(37 \mathrm{mg}$, $0.873 \mathrm{mmol})$ and dry THF (3 $\mathrm{mL})$. The mixture was stirred for about 10 min to completely dissolve $\mathrm{MnCl}_{2}$ and $\mathrm{LiCl}$ followed by cooling to $-10{ }^{\circ} \mathrm{C}$. A solution of the Grignard reagent in excess $(4 \mathrm{mmol})$ was added dropwise over $4 \mathrm{~min}$ and the mixture was then stirred for an additional 2 min before dropwise addition of the limiting Grignard reagent $(2 \mathrm{mmol})$ over $4 \mathrm{~min}$. The mixture was stirred for $20-30 \mathrm{~min}$ after which time the nitrogen flow was stopped and a balloon of dioxygen was connected through a septum with a needle. A continuous flow of dioxygen was allowed into the reaction flask for $10 \mathrm{~min}$ which caused the temperature to rise to $+10-+20^{\circ} \mathrm{C}$ and the color to change to black. Decane $(0.4 \mathrm{~mL}$, $2 \mathrm{mmol}$ ) was then injected as an internal standard for determining the yield by GC and the reaction was quenched with saturated ammonium chloride solution $(10 \mathrm{~mL})$. The mixture was extracted with EtOAc $(2 \times 10$ $\mathrm{mL}$ ) and the combined organic layers were concentrated and the residue purified by flash column chromatography.

4-Methoxy-1,1'-biphenyl:[7] Table 1 and Table 2, Entry 1. Purified by flash chromatography (heptane/EtOAc, 99:1) to afford a white solid. ${ }^{1} \mathrm{H}$ $\operatorname{NMR}\left(400 \mathrm{MHz}, \mathrm{CDCl}_{3}\right): \delta=3.86(\mathrm{~s}, 3 \mathrm{H}), 6.99(\mathrm{~d}, J=8.8 \mathrm{~Hz}, 2 \mathrm{H}), 7.31$ (t, $J=7.8 \mathrm{~Hz}, 1 \mathrm{H}$ ), 7.42 (dd, $J=8.5,6.9 \mathrm{~Hz}, 2 \mathrm{H}$ ), 7.55 (t, $J=8.2 \mathrm{~Hz}, 4$ H) ppm. ${ }^{13} \mathrm{C}$ NMR $\left(100 \mathrm{MHz}, \mathrm{CDCl}_{3}\right): \delta=55.2,114.0,126.5,128.0,128.5$, 133.6, 140.7, 159.0 ppm. MS: $m / z=184.10\left[\mathrm{M}^{+}\right]$.

4'-Methoxy-N,N-dimethyl-[1,1'-biphenyl]-4-amine:[13] Table 2, Entry 2. Purified by flash chromatography (heptane/EtOAc, 10:1) to afford a white solid. ${ }^{1} \mathrm{H}$ NMR (400 MHz, $\left.\mathrm{CDCl}_{3}\right): \delta=2.99(\mathrm{~s}, 6 \mathrm{H}), 3.85(\mathrm{~s}, 3 \mathrm{H}), 6.83(\mathrm{~d}$, $J=8.3 \mathrm{~Hz}, 2 \mathrm{H}), 6.96(\mathrm{~d}, J=8.3 \mathrm{~Hz}, 2 \mathrm{H}), 7.48$ (t, $J=9.0 \mathrm{~Hz}, 4 \mathrm{H}) \mathrm{ppm}$. ${ }^{13} \mathrm{C}$ NMR $\left(100 \mathrm{MHz}, \mathrm{CDCl}_{3}\right): \delta=40.7,55.2,113.0,113.9,127.2,127.2$, 133.7, 149.1, 158.1 ppm. MS: $m / z=227.00\left[\mathrm{M}^{+}\right]$.

4'-Methoxy-[1,1'-biphenyl]-4-carbonitrile:[14] Table 2, Entry 3. Purified by flash chromatography (heptane/EtOAc, 98:2) to yield a yellow solid. ${ }^{1} \mathrm{H}$ $\operatorname{NMR}\left(400 \mathrm{MHz}, \mathrm{CDCl}_{3}\right): \delta=3.86(\mathrm{~s}, 3 \mathrm{H}), 7.00(\mathrm{~d}, J=8.8 \mathrm{~Hz}, 2 \mathrm{H}), 7.54$ $(\mathrm{d}, J=8.8 \mathrm{~Hz}, 2 \mathrm{H}), 7.74-7.61(\mathrm{~m}, 4 \mathrm{H}) \mathrm{ppm} .{ }^{13} \mathrm{C} \mathrm{NMR}(100 \mathrm{MHz}$, $\left.\mathrm{CDCl}_{3}\right): \delta=55.8,110.5,115.0,119.5,127.5,128.8,131.9,133.0,145.6$, $160.6 \mathrm{ppm}$. MS: $\mathrm{m} / \mathrm{z}=209.00\left[\mathrm{M}^{+}\right]$.

2-(4-Methoxyphenyl)thiophene:[7] Table 2, Entry 4. Purified by flash chromatography (pentane) to give a white solid. ${ }^{1} \mathrm{H}$ NMR $(400 \mathrm{MHz}$, 
$\left.\mathrm{CDCl}_{3}\right): \delta=3.84(\mathrm{~s}, 3 \mathrm{H}), 6.92(\mathrm{~d}, J=8.8 \mathrm{~Hz}, 2 \mathrm{H}), 7.06(\mathrm{dd}, J=5.1,3.6$ $\mathrm{Hz}, 1 \mathrm{H}), 7.17-7.23(\mathrm{~m}, 2 \mathrm{H}), 7.54(\mathrm{~d}, J=8.8 \mathrm{~Hz}, 2 \mathrm{H}) \mathrm{ppm} .{ }^{13} \mathrm{C}$ NMR $\left(100 \mathrm{MHz}, \mathrm{CDCl}_{3}\right): \delta=55.8,114.7,122.5,124.3,127.7,128.4,144.8$, 159.6 ppm. MS: $m / z=189.95\left[\mathrm{M}^{+}\right]$.

3-(4-Methoxyphenyl)pyridine:[15] Table 2, Entry 5. Purified by flash chromatography (heptane/EtOAc, $3: 1$ ) to afford a white solid. ${ }^{1} \mathrm{H}$ NMR (400 MHz, $\mathrm{CDCl}_{3}$ ): $\delta=3.86(\mathrm{~s}, 3 \mathrm{H}), 7.02(\mathrm{~d}, J=8.8 \mathrm{~Hz}, 2 \mathrm{H}$ ), 7.37 (dd, J $=8.0,4.8 \mathrm{~Hz}, 1 \mathrm{H}), 7.52(\mathrm{~d}, J=8.8 \mathrm{~Hz}, 2 \mathrm{H}), 7.73-7.97(\mathrm{~m}, 1 \mathrm{H}), 8.54(\mathrm{dd}$ $J=5.0,1.5 \mathrm{~Hz}, 1 \mathrm{H}), 8.82(\mathrm{~d}, J=2.4 \mathrm{~Hz}, 1 \mathrm{H}) \mathrm{ppm} .{ }^{13} \mathrm{C} \mathrm{NMR}(100 \mathrm{MHz}$, $\left.\mathrm{CDCl}_{3}\right): \delta=55.9,115.1,124.2,128.7,130.4,134.8,137.0,147.8,160.3$ ppm. MS: $m / z=185.00\left[\mathrm{M}^{+}\right]$.

$\boldsymbol{N}, \boldsymbol{N}$-Dimethyl-[1,1'-biphenyl]-4-amine:[13] Table 2, Entry 6. Purified by flash chromatography (heptane/EtOAc, 10:1) to furnish a white solid. ${ }^{1} \mathrm{H}$ NMR (400 MHz, CDCl 3 ): $\delta=3.04(\mathrm{~s}, 6 \mathrm{H}), 6.87(\mathrm{~d}, J=8.3 \mathrm{~Hz}, 2 \mathrm{H}), 7.32$ $(\mathrm{t}, J=7.4 \mathrm{~Hz}, 1 \mathrm{H}), 7.46(\mathrm{t}, J=7.6 \mathrm{~Hz}, 2 \mathrm{H}), 7.58(\mathrm{~d}, J=8.4 \mathrm{~Hz}, 2 \mathrm{H})$, $7.63(\mathrm{~d}, J=7.6 \mathrm{~Hz}, 2 \mathrm{H}) \mathrm{ppm} .{ }^{13} \mathrm{C} \operatorname{NMR}\left(100 \mathrm{MHz}, \mathrm{CDCl}_{3}\right): \delta=41.1$, $113.3,126.4,126.7,128.2,129.1,129.8,141.6,150.3 \mathrm{ppm} . \mathrm{MS}: \mathrm{m} / \mathrm{z}=$ $197.15\left[\mathrm{M}^{+}\right]$

4'-Fluoro- $\mathbf{N}, \boldsymbol{N}$-dimethyl-[1,1'-biphenyl]-4-amine: Table 2, Entries 7 and 8. Purified by flash chromatography (heptane/EtOAc, 3:1) to yield a pink solid. ${ }^{1} \mathrm{H}$ NMR $\left(400 \mathrm{MHz}, \mathrm{CDCl}_{3}\right): \delta=3.01(\mathrm{~s}, 6 \mathrm{H}), 6.84(\mathrm{~d}, J=8.4 \mathrm{~Hz}, 2$ $\mathrm{H}), 7.09$ (t, $J=8.7 \mathrm{~Hz}, 2 \mathrm{H}), 7.55-7.42(\mathrm{~m}, 4 \mathrm{H}) \mathrm{ppm} .{ }^{13} \mathrm{C} \mathrm{NMR}(100 \mathrm{MHz}$ $\left.\mathrm{CDCl}_{3}\right): \delta=41.2,113.5,115.9(\mathrm{~d}, J=21 \mathrm{~Hz}), 128.2(\mathrm{~d}, J=7 \mathrm{~Hz}), 128.2$, $137.8(\mathrm{~d}, J=3 \mathrm{~Hz}), 150.2,160.8,162.1(\mathrm{~d}, J=244 \mathrm{~Hz})$ ppm. HRMS calcd. for $\mathrm{C}_{14} \mathrm{H}_{15} \mathrm{FN}[\mathrm{M}+\mathrm{H}]^{+} 216.1188$, found 216.1183

4-Fluoro-1,1'-biphenyl:[16] Table 2, Entry 9. Purified by flash chromatography (pentane) to furnish a white solid which contains small amounts of 1,1'-biphenyl and 4,4'-difluoro-1,1'-biphenyl. ${ }^{1} \mathrm{H}$ NMR (400 $\left.\mathrm{MHz}_{\mathrm{CDCl}}\right): \delta=7.19(\mathrm{td}, J=8.7,4.1 \mathrm{~Hz}, 2 \mathrm{H}), 7.42(\mathrm{td}, J=7.1,1.7 \mathrm{~Hz}$ $1 \mathrm{H}), 7.57-7.47(\mathrm{~m}, 2 \mathrm{H}), 7.61(\mathrm{td}, J=5.8,1.8 \mathrm{~Hz}, 4 \mathrm{H}) \mathrm{ppm} .{ }^{13} \mathrm{C} \mathrm{NMR}$ $\left(100 \mathrm{MHz} \mathrm{CDCl}_{3}\right): \delta=116.0(\mathrm{~d}, J=21 \mathrm{~Hz}), 127.7,128.9(\mathrm{~d}, J=8 \mathrm{~Hz})$, $129.2,129.3,136.8(\mathrm{~d}, J=3 \mathrm{~Hz}), 140.7,162.6(\mathrm{~d}, J=254 \mathrm{~Hz}) \mathrm{ppm} . \mathrm{MS}$ : $\mathrm{m} / \mathrm{z}=172.10\left[\mathrm{M}^{+}\right]$

4-Fluoro-4'-methyl-1,1'-biphenyl: [17] Table 2, Entry 10. Purified by flash chromatography (pentane) to give a white solid which contains a small amount of 4,4'-dimethyl-1,1'-biphenyl. ${ }^{1} \mathrm{H}$ NMR $\left(400 \mathrm{MHz}, \mathrm{CDCl}_{3}\right): \delta=$ 2.22 (s, $3 \mathrm{H}$ ), 6.94 (td, $J=8.7,2.9 \mathrm{~Hz}, 2 \mathrm{H}), 7.07$ (dd, $J=8.2,1.9 \mathrm{~Hz}, 2$ H), 7.21-7.43 (m, $4 \mathrm{H})$ ppm. ${ }^{13} \mathrm{C}$ NMR $\left(100 \mathrm{MHz}, \mathrm{CDCl}_{3}\right): \delta=21.5,116.0$ (d, $J=21 \mathrm{~Hz}), 127.3,128.9$ (d, $J=9.0 \mathrm{~Hz}), 130.0,137.5,137.7$ (d, $J=$ $2.0 \mathrm{~Hz}), 137.8,162.7(\mathrm{~d}, J=244 \mathrm{~Hz}) \mathrm{ppm}$. MS: $m / z=185.95\left[\mathrm{M}^{+}\right]$

4'-Fluoro-[1,1'-biphenyl]-4-carbonitrile:[17] Table 2, Entry 11. Purified by flash chromatography (heptane/EtOAc, 98:2) to give a yellow solid. ${ }^{1} \mathrm{H}$ NMR $\left(400 \mathrm{MHz}_{\mathrm{CDCl}}\right): \delta=7.17(\mathrm{t}, J=8.6 \mathrm{~Hz}, 2 \mathrm{H}), 7.56$ (dd, $J=8.8$, $5.2 \mathrm{~Hz}, 2 \mathrm{H}), 7.64(\mathrm{~d}, J=8.4 \mathrm{~Hz}, 2 \mathrm{H}), 7.72(\mathrm{~d}, J=8.6 \mathrm{~Hz}, 2 \mathrm{H}) \mathrm{ppm} .{ }^{13} \mathrm{C}$ NMR $\left(100 \mathrm{MHz}, \mathrm{CDCl}_{3}\right): \delta=111.1,116.3(\mathrm{~d}, J=21 \mathrm{~Hz}), 119.0,127.7$, $129.1(\mathrm{~d}, J=8 \mathrm{~Hz}), 132.8,135.4,144.8,163.4(\mathrm{~d}, J=247 \mathrm{~Hz}) \mathrm{ppm}$. MS: $\mathrm{m} / \mathrm{z}=196.95\left[\mathrm{M}^{+}\right]$.

4-Chloro-4'-fluoro-1,1'-biphenyl:[16] Table 2, Entries 12 and 13. Purified by flash chromatography (pentane) to afford a white solid which contains a small amount of 4,4'-dichloro-1,1'-biphenyl. ${ }^{1} \mathrm{H} \mathrm{NMR}\left(400 \mathrm{MHz}, \mathrm{CDCl}_{3}\right)$ : $\delta=7.13(\mathrm{td}, J=8.8,2.7 \mathrm{~Hz}, 2 \mathrm{H}), 7.35-7.53(\mathrm{~m}, 6 \mathrm{H}) \mathrm{ppm} .{ }^{13} \mathrm{C}$ NMR $(100$ $\mathrm{MHz}_{\mathrm{CDCl}}$ ): $\delta=116.2(\mathrm{~d}, J=22 \mathrm{~Hz}), 128.7,129.0(\mathrm{~d}, J=8 \mathrm{~Hz}), 129.4$, 133.9, $136.6(\mathrm{~d}, J=4 \mathrm{~Hz}), 139.1,163.1(\mathrm{~d}, J=245 \mathrm{~Hz})$ ppm. MS: $m / z=$ $206.10\left[\mathrm{M}^{+}\right]$.

4-Chloro-1,1'-biphenyl::[18] Table 2, Entry 14. Purified by flash chromatography (pentane) to give a white solid. ${ }^{1} \mathrm{H}$ NMR $(400 \mathrm{MHz}$, $\left.\mathrm{CDCl}_{3}\right): \delta=7.58-7.48(\mathrm{~m}, 4 \mathrm{H}), 7.48-7.33(\mathrm{~m}, 5 \mathrm{H}) \mathrm{ppm} .{ }^{13} \mathrm{C}$ NMR $(100$ $\left.\mathrm{MHz}, \mathrm{CDCl}_{3}\right): \delta=127.5,128.5,128.9,129.3,133.8,140.1,140.5$ ppm. MS: $m / z=188.05\left[\mathrm{M}^{+}\right]$.
4-Chloro-4'-methoxy-1,1'-biphenyl:[18] Table 2, Entry 15. Purified by flash chromatography (heptane/EtOAc, 98:2) to afford a white solid. ${ }^{1} \mathrm{H}$ $\operatorname{NMR}\left(400 \mathrm{MHz}, \mathrm{CDCl}_{3}\right): \delta=3.86(\mathrm{~s}, 3 \mathrm{H}), 6.98(\mathrm{~d}, J=8.8 \mathrm{~Hz}, 2 \mathrm{H}), 7.38$ $(\mathrm{d}, J=8.6 \mathrm{~Hz}, 2 \mathrm{H}), 7.44-7.55(\mathrm{~m}, 4 \mathrm{H}) \mathrm{ppm} .{ }^{13} \mathrm{C} \mathrm{NMR}(100 \mathrm{MHz}$ $\left.\mathrm{CDCl}_{3}\right): \delta=55.8,114.8,128.4,128.5,129.3,132.9,133.1,139.7,159.8$ ppm. MS: $m / z=218.05\left[\mathrm{M}^{+}\right]$.

2-(4-Fluorophenyl)thiophene:[15] Table 2, Entry 16. Purified by flash chromatography (pentane) to yield a white solid. ${ }^{1} \mathrm{H}$ NMR $(400 \mathrm{MHz}$ $\left.\mathrm{CDCl}_{3}\right): \delta=7.06-7.17(\mathrm{~m}, 2 \mathrm{H}), 7.24-7.31(\mathrm{~m}, 2 \mathrm{H}), 7.47-7.54(\mathrm{~m}, 2 \mathrm{H})$, 7.59 (dd, $J=8.8,5.2 \mathrm{~Hz}, 1 \mathrm{H}$ ) ppm. ${ }^{13} \mathrm{C} \mathrm{NMR}\left(100 \mathrm{MHz}, \mathrm{CDCl}_{3}\right): \delta=$ $115.5(\mathrm{~d}, J=21 \mathrm{~Hz}), 122.9,124.6,127.9,128.4(\mathrm{~d}, J=9.0 \mathrm{~Hz}), 136.2$, 143.1, $162.2(\mathrm{~d}, J=258 \mathrm{~Hz})$ ppm. MS: $m / z=165.95\left[\mathrm{M}^{+}\right]$.

3-(4-Fluorophenyl)pyridine:[17] Table 2, Entry 17. Purified by flash chromatography (heptane/EtOAc, $4: 1$ ) to yield a yellow liquid. ${ }^{1} \mathrm{H}$ NMR $\left(400 \mathrm{MHz}_{\mathrm{CDCl}}\right.$ ) : $\delta=7.14(\mathrm{t}, J=8.7 \mathrm{~Hz}, 2 \mathrm{H}$ ), 7.34 (ddd, $J=7.9,4.8$, $0.8 \mathrm{~Hz}, 1 \mathrm{H}$ ), 7.51 (dd, $J=8.9,5.2 \mathrm{~Hz}, 2 \mathrm{H}$ ), 7.81 (ddd, $J=7.9,2.4,1.6$ $\mathrm{Hz}, 1 \mathrm{H}), 8.56(\mathrm{dd}, J=4.8,1.6 \mathrm{~Hz}, 1 \mathrm{H}), 8.78(\mathrm{dd}, J=2.4,0.9 \mathrm{~Hz}, 1 \mathrm{H})$ ppm. ${ }^{13} \mathrm{C}$ NMR $\left(100 \mathrm{MHz}, \mathrm{CDCl}_{3}\right): \delta=116.2(\mathrm{~d}, J=21 \mathrm{~Hz}), 123.7,128.9$ (d, $J=8 \mathrm{~Hz}), 134.0$ (d, $J=3 \mathrm{~Hz}), 134.4,135.8,148.1,148.5,163.0$ (d, $J$ $=248 \mathrm{~Hz}) \mathrm{ppm}$. MS: $\mathrm{m} / \mathrm{z}=173.0\left[\mathrm{M}^{+}\right]$

2-(4-Fluorophenyl)furan:[19] Table 2, Entry 18. Purified by flash chromatography (pentane) to furnish a white solid which contains a small amount of 4,4'-difluoro-1,1'-biphenyl. ${ }^{1} \mathrm{H}$ NMR (400 $\left.\mathrm{MHz}, \mathrm{CDCl}_{3}\right): \delta=$ 6.41-6.69 (m, 1 H), 6.96-7.21 (m, $2 \mathrm{H}), 7.49$ (dd, J = 8.8, 5.2 Hz, $2 \mathrm{H})$ 7.64 (dd, $J=8.9,5.3 \mathrm{~Hz}, 2 \mathrm{H}$ ) ppm. ${ }^{13} \mathrm{C} \mathrm{NMR}\left(100 \mathrm{MHz}, \mathrm{CDCl}_{3}\right): \delta=$ 105.1, 112.1, $116.1(\mathrm{~d}, J=21 \mathrm{~Hz}), 127.7(\mathrm{~d}, J=3 \mathrm{~Hz}), 129.0(\mathrm{~d}, J=8$ $\mathrm{Hz}), 142.5,153.6,162.9\left(\mathrm{~d}, J=244 \mathrm{~Hz}\right.$ ) ppm. MS: $m / z=162.05\left[\mathrm{M}^{+}\right]$

2-Methoxy-1,1'-biphenyl: ${ }^{[16]}$ Table 2, Entry 19. Purified by flash chromatography (heptane/EtOAc, 99:1) to yield a white solid. ${ }^{1} \mathrm{H}$ NMR $\left(400 \mathrm{MHz}, \mathrm{CDCl}_{3}\right): \delta=3.94(\mathrm{~s}, 3 \mathrm{H}), 7.14(\mathrm{dd}, J=8.8,3.4 \mathrm{~Hz}, 1 \mathrm{H}), 7.21$ (ddt, $J=10.3,5.9,2.0 \mathrm{~Hz}, 1 \mathrm{H}$ ), 7.51 (tdd, $J=9.6,4.8,2.0 \mathrm{~Hz}, 3 \mathrm{H}$ ), 7.57-7.62 (m, $2 \mathrm{H}), 7.70-7.77(\mathrm{~m}, 2 \mathrm{H}) \mathrm{ppm} .{ }^{13} \mathrm{C} \mathrm{NMR}(100 \mathrm{MHz}$, $\left.\mathrm{CDCl}_{3}\right): \delta=55.2,111.0,120.6,126.6,127.7,128.4,129.3,130.5,130.6$, 138.3, $156.2 \mathrm{ppm}$. MS: $\mathrm{m} / \mathrm{z}=184.10\left[\mathrm{M}^{+}\right]$

3'-Fluoro- $\mathbf{N}, \boldsymbol{N}$-dimethyl-[1,1'-biphenyl]-4-amine: Table 2, Entry 20. Purified by flash chromatography (heptane/EtOAc, 20:1) to afford a light yellow solid. ${ }^{1} \mathrm{H}$ NMR $\left(400 \mathrm{MHz}, \mathrm{CDCl}_{3}\right): \delta=3.32(\mathrm{~s}, 6 \mathrm{H}), 7.12(\mathrm{~d}, \mathrm{~J}=$ $8.4 \mathrm{~Hz}, 2 \mathrm{H}), 7.57(\mathrm{~d}, J=10.2 \mathrm{~Hz}, 1 \mathrm{H}), 7.66(\mathrm{~s}, 2 \mathrm{H}), 7.73-7.93(\mathrm{~m}, 3 \mathrm{H})$ ppm. ${ }^{13} \mathrm{C}$ NMR $\left(100 \mathrm{MHz}, \mathrm{CDCl}_{3}\right): \delta=40.4,112.6(\mathrm{~d}, J=21 \mathrm{~Hz}), 112.6$ $(\mathrm{d}, J=21 \mathrm{~Hz}), 121.6(\mathrm{~d}, J=2 \mathrm{~Hz}), 127.5,127.7,129.0,129.8(\mathrm{~d}, J=9$ $\mathrm{Hz}), 143.3$ (d, $J=8 \mathrm{~Hz}$ ), 163.1 (d, $J=244.8 \mathrm{~Hz}$ ) ppm. HRMS: calcd. for $\mathrm{C}_{14} \mathrm{H}_{15} \mathrm{FN}[\mathrm{M}+\mathrm{H}]^{+}$216.1188, found 216.1183.

3-Chloro-1,1'-biphenyl:[20] Table 2, Entry 21. Purified by flash chromatography (heptane/EtOAc, 99:1) to give a yellow liquid. ${ }^{1} \mathrm{H}$ NMR $\left(400 \mathrm{MHz} \mathrm{CDCl}_{3}\right): \delta=7.33-7.45(\mathrm{~m}, 3 \mathrm{H}), 7.46-7.53(\mathrm{~m}, 3 \mathrm{H}), 7.56-7.69$ $(\mathrm{m}, 3 \mathrm{H}) \mathrm{ppm} .{ }^{13} \mathrm{C}$ NMR $\left(100 \mathrm{MHz}, \mathrm{CDCl}_{3}\right): \delta=125.1,126.9,127.1$, $127.7,128.7,129.8,134.4,139.6,142.9$ ppm. MS: $m / z=188.05\left[\mathrm{M}^{+}\right]$

3-Methoxy-1,1'-biphenyl:[16] Table 2, Entry 22. Purified by flash chromatography (heptane/EtOAc, 99:1) to afford a yellow solid. ${ }^{1} \mathrm{H}$ NMR $\left(400 \mathrm{MHz}, \mathrm{CDCl}_{3}\right): \delta=3.98(\mathrm{~s}, 3 \mathrm{H}), 7.08(\mathrm{dd}, J=8.2,1.1 \mathrm{~Hz}, 1 \mathrm{H}), 7.31-$ $7.43(\mathrm{~m}, 2 \mathrm{H}), 7.52(\mathrm{tt}, J=6.5,1.2 \mathrm{~Hz}, 2 \mathrm{H}), 7.57-7.67(\mathrm{~m}, 2 \mathrm{H}), 7.74$ $7.84(\mathrm{~m}, 2 \mathrm{H}) \mathrm{ppm} .{ }^{13} \mathrm{C}$ NMR $\left(100 \mathrm{MHz}, \mathrm{CDCl}_{3}\right): \delta=55.5,113.0,113.3$, $120.0,127.5,127.8,129.1,130.1,141.4,143.1,160.3 \mathrm{ppm} . \mathrm{MS}: \mathrm{m} / z=$ $184.09\left[\mathrm{M}^{+}\right]$.

\section{Acknowledgements}


We thank the Danish Council for Independent Research Technology and Production Sciences for financial support.

Keywords: Cross-coupling $\bullet$ Grignard reagent $\bullet$ Homogeneous catalysis $\cdot$ Manganese $\cdot$ Oxygen

[1] a) S. Jeanmart, A. J. F. Edmunds, C. Lamberth, M. Pouliot, Bioorg Med. Chem. 2016, 24, 317-341. b) G. Marzano, C. V. Ciasca, F. Babudri, G. Bianchi, A. Pellegrino, R. Po, G. M. Farinola, Eur. J. Org Chem. 2014, 6583-6614. c) J. Magano, J. R. Dunetz, Chem. Rev. 2011 111, 2177-2250. d) G. Bringmann, T. Gulder, T. A. M. Gulder, M. Breuning, Chem. Rev. 2011, 111, 563-639.

[2] C. Liu, H. Zhang, W. Shi, A. Lei, Chem. Rev. 2011, 111, 1780-1824.

[3] a) Y. Zhu, T. Xiong, W. Han, Y. Shi, Org. Lett. 2014, 16, 6144-6147; b) A. P. I. Bhat, F. Inam, B. R. Bhat, Eur. J. Org. Chem. 2013, 7139-7144 C) G. Kiefer, L. Jeanbourquin, K. Severin, Angew. Chem. 2013, 125, 6422-6425; Angew. Chem. Int. Ed. 2013, 52, 6302-6305; d) S.-K. Hua, Q.-P. Hu, J. Ren, B.-B. Zeng, Synthesis 2013, 518-526; e) P. I. Aparna, B. R. Bhat, J. Mol. Catal. A: Chem. 2012, 358, 73-78; f) Z. Zhou, W Xue, J. Organomet. Chem. 2009, 694, 599-603; g) W. Liu, A. Lei, Tetrahedron Lett. 2008, 49, 610-613; h) G. Cahiez, A. Moyeux, J. Buendia, C. Duplais, J. Am. Chem. Soc. 2007, 129, 13788-13789; i) G Cahiez, C. Chaboche, F. Mahuteau-Betzer, M. Ahr, Org. Lett. 2005, 7, 1943-1946; j) T. Nagano, T. Hayashi, Org. Lett. 2005, 7, 491-493.

[4] a) T. Amaya, R. Suzuki, T. Hirao, Chem. Commun. 2016, 52, 7790 7793; b) T. Korenaga, K. Nitatori, H. Muraoka, S. Ogawa, K. Shimada Org. Lett. 2015, 17, 5500-5503; c) M.S. Maji, T. Pfeifer, A. Studer, Angew. Chem. 2008, 120, 9690-9692; Angew. Chem. Int. Ed. 2008, 47, 9547-9550.

[5] a) Y. Moglie, E. Mascaró, F. Nador, C. Vitale, G. Radivoy, Synth. Commun. 2008, 38, 3861-3874; b) A. Krasovskiy, A. Tishkov, V. del Amo, H. Mayr, P. Knochel, Angew. Chem. 2006, 118, 5132-5136 Angew. Chem. Int. Ed. 2006, 45, 5010-5014; c) A. Inoue, K. Kitagawa H. Shinokubo, K. Oshima, Tetrahedron 2000, 56, 9601-9605; d) J.-W Cheng, F.-T. Luo, Tetrahedron Lett. 1988, 29, 1293-1294.
[6] M. Mayer, W. M. Czaplik, A. J. von Wangelin, Synlett 2009, 2919-2923.

[7] G. Cahiez, C. Duplais, J. Buendia, Angew. Chem. 2009, 121, 6859 6862; Angew. Chem. Int. Ed. 2009, 48, 6731-6734.

[8] In reference 7 the amount of $\mathrm{MnCl}_{2} \cdot 2 \mathrm{LiCl}$ is reported as $20 \%$, but according to the supporting information the percentage is calculated from the Grignard reagent in excess (2.5 equiv.) and not from the limiting agent (1 equiv.). As a result, it is more appropriate to list the amount as $70 \%$ since the yields are also based on the limiting Grignard reagent.

[9] A. Bottoni, G. Cahiez, M. Calvaresi, A. Moyeux, P. Giacinto, G. P. Miscione, J. Organomet. Chem. 2016, 814, 25-34.

[10] G. Cahiez, C. Duplais, J. Buendia, Chem. Rev. 2009, 109, 1434-1476.

[11] a) S. H. Christensen, T. Holm, R. Madsen, Tetrahedron 2014, 70, 4942 4946; b) S. H. Christensen, T. Holm, R. Madsen, Tetrahedron 2014, 70 1478-1483; c) G. Osztrovszky, T. Holm, R. Madsen, Org. Biomol. Chem. 2010, 8, 3402-3404.

[12] A. Sølvhøj, A. Ahlburg, R. Madsen, Chem. Eur. J. 2015, 21, 16272 16279.

[13] Q. Wu, R. Jin, C. Kang, W. Chen, Z. Bian, X. Ma, J. Ding, H. Guo, X. Qiu, L. Gao, Chem. Res. Chin. Univ. 2016, 32, 55-61.

[14] J. J. Hirner, S. A. Blum, Organometallics 2011, 30, 1299-1302.

[15] M. Feuerstein, H. Doucet, M. Santelli, J. Organomet. Chem. 2003, 687, 327-336.

[16] J. Mao, Q. Hua, G. Xie, J. Guo, Z. Yao, D. Shi, S. Ji, Adv. Synth. Catal. 2009, 351, 635-641.

[17] L. Ning, L. Chun, Z. Zilin, J. Organomet. Chem. 2011, 696, 2641-2647.

[18] F.-Y. Tsai, B.-N. Lin, M.-J. Chen, C.-Y. Mou, S.-T. Liu, Tetrahedron 2007, 63, 4304-4309.

[19] L. Zhi, H. Zhang, Z. Yang, W. Liu, B. Wang, Chem. Commun. 2016, 52, 6431-6434.

[20] L. Emmanuvel, A. Sudalai, ARKIVOC 2007, (14), 126-133. 
Entry for the Table of Contents (Please choose one layout)

Layout 1:

\section{FULL PAPER}

Text for Table of Contents

*one or two words that highlight the emphasis of the paper or the field of the study

Layout 2:

\section{FULL PAPER}

((Insert TOC Graphic here: max. width: $5.5 \mathrm{~cm}$; max. height: $5.0 \mathrm{~cm}$; NOTE: the final letter height should not be less than $2 \mathrm{~mm}$.))

\section{Key Topic*}

Author(s), Corresponding Author(s)*

Page No. - Page No.

Title

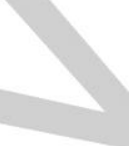

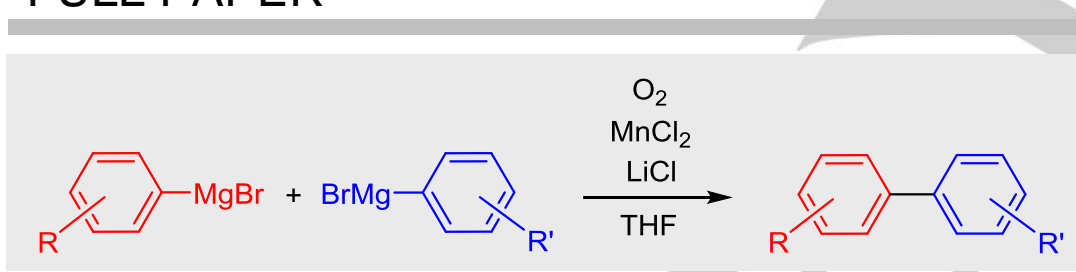

Oxidative cross coupling of Grignard reagents can be achieved in good yield for a number of substituted arylmagnesium bromides where the competing homocoupling is a slow reaction

\section{Cross Coupling}

Hajar Golshahi Ghaleshahi, Giuseppe Antonacci, Robert Madsen*

Page No. - Page No.

Manganese-Catalyzed Aerobic Heterocoupling of Aryl Grignard Reagents

*one or two words that highlight the emphasis of the paper or the field of the study 